\title{
RUANG PUBLIK PENGEMBANGAN DIGITAL DAN KULINER MASYARAKAT KOTA BAMBU SELATAN DENGAN PENDEKATAN RUANG KETIGA
}

\author{
Hebert Nathan ${ }^{1)}$, Doddy Yuono ${ }^{2)}$ \\ 1) Program Studi S1 Arsitektur, Fakultas Teknik, Universitas Tarumanagara, hebertnathan.w@gmail.com \\ 2) Program Studi S1 Arsitektur, Fakultas Teknik, Universitas Tarumanagara, masdoddyyuono@gmail.com
}

Masuk: 14-07-2020, revisi: 01-08-2020, diterima untuk diterbitkan: 24-09-2020

\begin{abstract}
Abstrak
Jakarta merupakan ibukota yang dikenal sebagai pusat ekonomi dan memiliki daya tarik untuk mengadu nasib dengan datang dan mencari pekerjaan sehingga muncul permasalahan yaitu terjadinya penggumpalan tenaga kerja. Banyaknya tenaga kerja yang datang ke Jakarta ternyata memunculkan masalah baru, yaitu rendahnya kualitas seperti pendidikan dan moral. Rendahnya tingkat pendidikan dari individu yang datang ini menyebabkan rendahnya taraf hidup yang dimana memunculkan permasalahan lainnya, yaitu memunculkan masalah-masalah sosial seperti meningkatnya pengangguran, meningkatnya kemiskininan, memunculkan daerah-daerah kumuh, dan meningkatnya kriminalitas. Masyarakat Kota Bambu Selatan memandang pendidikan merupakan sesuatu yang tidak penting. Masyarakat Kota Bambu Selatan lebih memilih untuk terjun langsung ke masyarakat untuk bekerja, namun pada kenyataannya masyarakat pada umumnya menjadikan pendidikan sebagai tolak ukur bagaimana seseorang mampu untuk bekerja dengan baik. Tenaga dan waktu yang berlebih, namun kurangnya fasilitas yang memadai dapat menyebabkan meningkatnya kesenjangan pada masyarakat. Dari masalah tersebut, penyediaan Third Place diharapkan dapat mewadahi masyarakat Kota Bambu Selatan sehingga dapat meningkatkan kualitas hidup masyarakat Kota Bambu Selatan. Dengan penyediaan area tebuka, diharapkan juga masyarakat Kota Bambu Selatan dapat berinteraksi satu dengan lainnya sehingga dapat menumbuhkan rasa simpati dan empati.
\end{abstract}

Kata kunci: Kemiskinan; Pendidikan; Ruang Publik; Sumber Daya Manusia

\begin{abstract}
Jakarta is a capital known as the economic center and has the attraction to try one's luck by coming and looking for work so that the problem arises, namely the clumping of labor. The large number of workers coming to Jakarta has led to new problems, namely poor quality such as education and morals. The low level of education of individuals who come this causes a low standard of living which raises other problems, namely social problems such as rising unemployment, increasing poverty, raising slums, and increasing crime. Kota Bambu Selatan community views education as something that is not important. Kota Bambu Selatan community prefers to go directly to the community to work, but in reality the community in general makes education as a benchmark for how someone is able to work well. Excessive labor and time, but the lack of adequate facilities can lead to increased disparities in society. From this problem, the provision of Third Place is expected to accommodate the community of Kota Bambu Selatan so as to improve the quality of life of the people of Kota Bambu Selatan. By providing open areas, it is also hoped that the Kota Bambu Selatan community will be able to interact with each other so as to foster a sense of sympathy and empathy.
\end{abstract}

Keywords : Education; Human Resource; Poverty; Public Space 


\section{PENDAHULUAN}

\section{Latar Belakang}

Jakarta sebagai ibukota dikenal sebagai penggerak sistem perekonomian Indonesia dengan jumlah penduduk yang meningkat setiap tahunnya yang dimana berdasarkan data Badan Pusat Statistik, jumlah penduduk DKI Jakarta pada tahun 2015 - 2017 meningkat dari 10,18 juta jiwa menjadi 10,37 juta jiwa, yang artinya selama dua tahun itu jumlah penduduk di Ibu Kota bertambah 269 jiwa setiap hari atau 11 orang per jam. Jakarta dikenal juga sebagai kota yang tidak pernah berhenti beraktivitas sehingga setiap harinya Jakarta selalu diwarnai dengan kesibukan penduduknya. Dengan kepadatan yang tinggi dan aktivitas yang tidak pernah berhenti, masyarakat ibukota diharuskan berjuang untuk bertahan hidup. Dan disisi lainnya, kondisi seperti itu juga mengharuskan mereka untuk memperhatikan kualitas hidupnya. Kondisi kota yang padat dan segalanya berjalan dengan sangat cepat tentu saja memberikan tekanan bagi penduduk yang tinggal di kota tersebut, terlebih transportasi yang belum memadai, penduduk yang sangat padat, dan beragam problematika pada kota-kota besar di negara berkembang.

Pengamat ekonomi Imaduddin Abdullah dari Universitas Indonesia mengatakan karena beragamnya persaingan yang terjadi di kota-kota besar, biaya hidup di kota menjadi tinggi. Sementara itu belum tentu semua penduduk memiliki keterampilan yang sesuai untuk mengisi lapangan pekerjaan yang terbatas. Minimnya keterampilan dan rendahnya taraf pendidikan para urban menjadi faktor tingginya angka pengangguran di DKI Jakarta. Meskipun sebenarnya potensi yang dimiliki mereka merupakan faktor pokok yang dibutuhkan dalam aktivitas seharihari di Jakarta. Hal ini pun terlihat jelas di kawasan Kota Bambu Selatan, Jakarta Barat.

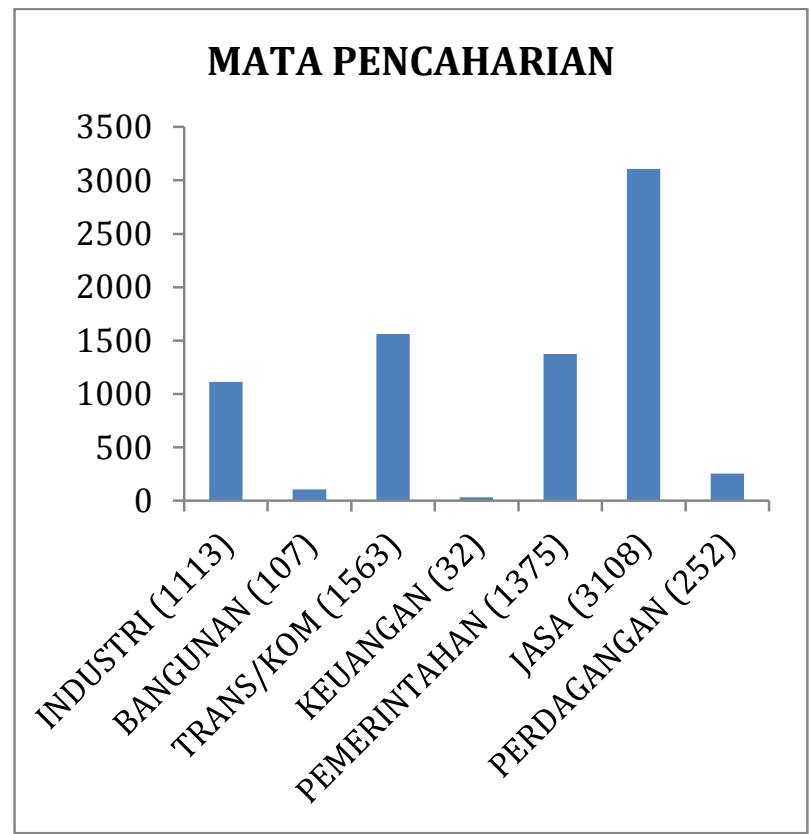

Gambar 1. Grafik Mata Pencaharian

Sumber: Badan Pusat Statistik

Berdasarkan data Badan Pusat Statistik, penduduk di Kota Bambu Selatan mencetak 24.957 jiwa, jika dilihat dari status pekerjaan yang tertera diatas. Disimpulkan bahwa estimasi total pengangguran, pekerjaan yang belum terdata, dan penduduk yang masih bersekolah adalah 17.407 jiwa. 
Berdasarkan hasil pengamatan, pengangguran yang terjadi pada kawasan ini didasari oleh rendahnya taraf pendidikan para penduduk secara garis besar. Hal ini membuat hilangnya kesadaran akan potensi yang mereka miliki sendiri dikarenakan desakan kebutuhan mereka sehari-hari. Adapun dampak yang dihasilkan oleh tingginya angka pengangguran terhadap aktivitas dan kondisi fisik Kota Bambu Selatan, yaitu adalah timbulnya pemukiman kumuh, tingginya angka PMKS, hingga isu penyebaran narkoba.
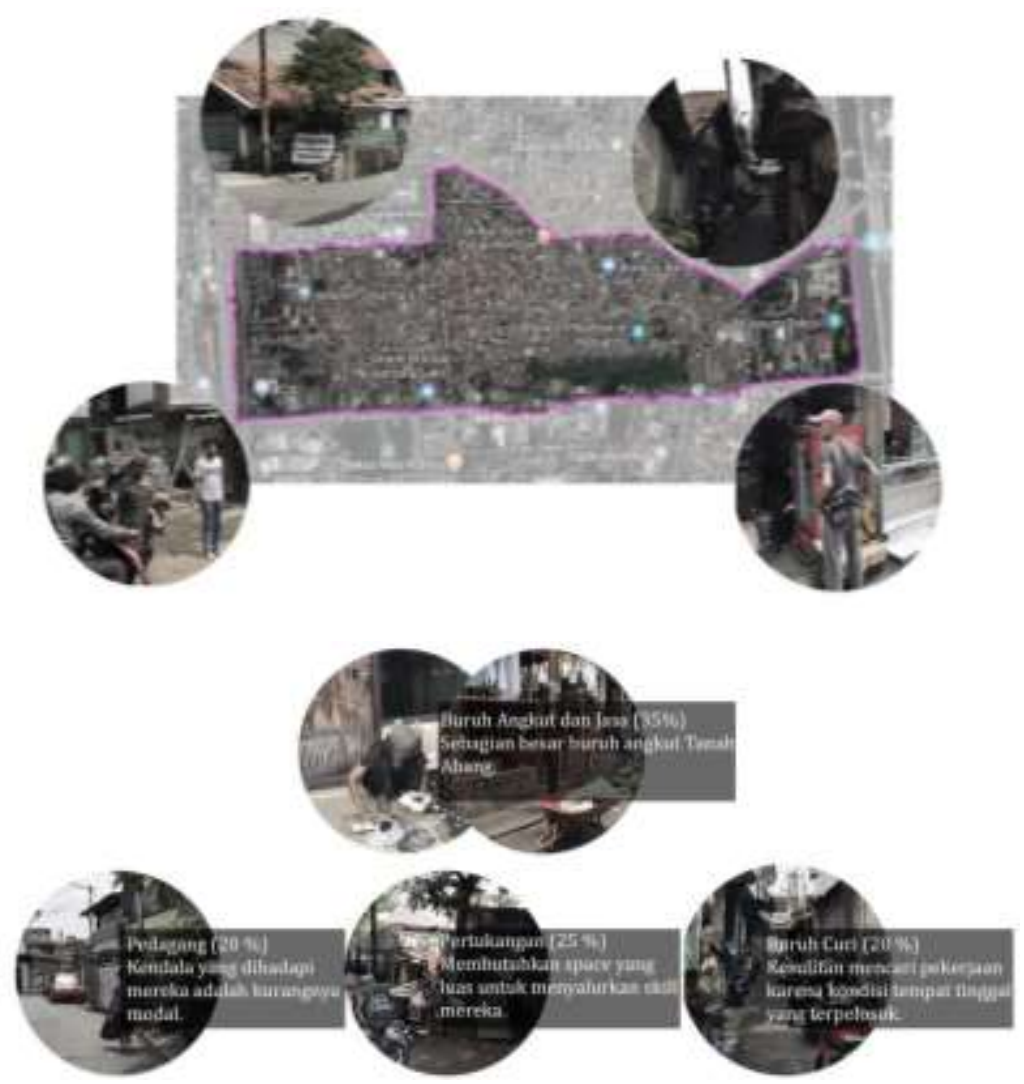

Gambar 2. Isu dan Keadaan Sekitar

Sumber: Dokumentasi Pribadi, 2020

Berdasarkan hasil pengamatan, dampak pengangguran yang terjadi seolah memendam potensipotensi urban kawasan Kota Bambu Selatan, Sehingga untuk menangani permasalahan yang ada, penulis memusatkan pada kebutuhan dan kebiasaan para penduduk dalam kegiatan seharihari. Berdasarkan potensi dan permasalahan yang ada, dapat disimpulkan bahwa dibutuhkan adanya suatu wadah arsitektur yang bersifat memperbaiki sumber daya manusia pada kawasan ini. Maka itu, penggabungan antara Ruang Publik dan Fasilitas Pelatihan dapat menjadi solusi yang baik dalam menanggulanginya.

\section{Rumusan Permasalahan}

Bagaimana rancangan yang akan dikerjakan akan mampu mewadahi kebutuhan masyarakat?; Apakah rancangan akan memberikan dampak positif bagi kualitas hidup masyarakat sekitar?; Bagaimana proyek dapat memenuhi fungsi Third Place didalam masyarakat yang sangat majemuk?

\section{Tujuan}

Sebagai seorang arsitek yang memiliki tingkat kepekaan dan kepedulian terhadap pembangunan seperti yang telah dijabarkan diatas, maka dengan proyek yang berjudul "Ruang Publik Pengembangan Digital dan Kuliner Masyarakat Kota Bambu Selatan Sebagai Ruang Ketiga" ini dapat meningkatkan taraf hidup masyarakat Kota Bambu Selatan secara hard skill maupun soft 
skill. Selain itu adapun maksud dan tujuan proyek ini adalah sebagai berikut :

a. Bekerja sama dengan pemerintah untuk mewadahi peningkatan SDM

b. Meningkatkan kepedulian masyarakat terhadap norma sosial

c. Mengubah pandangan masyarakat terhadap daerah Kota Bambu Selatan

d. Menjadikan tempat ini sebagai tempat yang dapat mewadahi kegiatan dengan basis komunitas

\section{KAJIAN LITERATUR}

\section{The Third Place}

The Third Place adalah tempat yang merupakan pemenuh kebutuhan masyarakat, selain rumah maupun tempat kerjanya. Third place adalah tempat public yang netral, sebagai tempat alternative yang dapat digunakan untuk berbagai aktivitas dan dapat digunakan oleh siapa saja. The Third Place merupakan anchor dari suatu wilayah yang berfungsi sebagai tempat bagi komunitas yang ada, tempat yang mempertemukan masyarkat disekitarnya. Masyarakat kota kemudian mencari hiburan atau bertemu dengan teman dipusat perbelanjaan. Kondisi ini menyebabkan menamurnya pusat komersil seperti mall. Mall menjamur karena adanya banyak atraksi dan market gimmick yang menyebabkan hilangnya unsur interaki antar sesame. Interaksi sangatlah diperlukan untuk membina rasa empati, kepedulian, daya nalar, proaktif dan hal lain terhadap sesama manusia.

Dalam perkembangannya, pemisahan antara kawasan pemukiman dan kawasan kerja memunculkan kritik terhadap revolusi industri karena dianggap tidak manusiawi dan tidak menyediakan tempat atau kawasan rekreasi untuk para pekerja. Pembangunan pemukiman yang individual berpengaruh pada kehidupan sosial masyarakat. Dimana antar masyarakat tidak saling mengenal, meskipun dalam satu lingkungan. Lingkungan pemukiman yang terbentuk terasa sangat membosankan dan mengisolasi masyarakat. Aktivitas masyarakat khususnya remaja lebih banyak terjadi di dalam rumah dan tempat kerjayang secara menerus menimbulkan rasa bosan, namun ironisnya masyarakat tidak menemukan tempat di luar lingkungan rumah untuk berkegiatan dan berkumpul antar sesama remaja yang sebaya. Oleh karena itu dampak dari pemisahan pemukiman pada era revolusi industri adalah kebutuhan akan Tempat Ketiga (third place) guna menjembatani kehidupan dalam rumah dan aktifitas kerja dengan kegiatan informal.

\section{Open Architecture}

Open Architecture sebagai third place dapat didefinisikan dengan melihat hal-hal penting yang terkait dengan konteks kebutuhan masyarakat kota dan modernitas yang berorientasi pada teknologi, informasi dan individu. Dalam merancang arsitektur, terkadang perlu mencari kearifan diluar dari masyarakat kota. Masyarakat kota modern yang majemuk memiliki ciri lebih individual dan lebih sensitive terhadap personal space-nya. Kondisi ini terkadang menyebabkan segregasi dan gesekan antar individu, sehingga perbedaan public private merupakan hal yang penting. Arsitektur vernacular, dimana public dan private itu bersifat blur sangat berbeda dibandingan dengan konsep ruang arsitektur barat yang sangat mementingkan ke-privat-aanya. Namun dalam open architecture, konflik public privat ini menjadi hal unik yang berpotensi untuk dikembangkan. Open Architecture yang berfungsi sebagai ruang antara, ruang yang bukan tempat tinggal dan bukan tempat kerja. Open Architecture merupakan system yang terbuka dan mampu beradaptasi dengan kepentingan terpilih. Konflik-konflik yang terjadi dari masyarakat kota dapat dipecahan atau dilakukan pendekatan melalui rangkaian pendeketan desain dan juga strategi perancangan.

Open Architecture menjadi kesempatan untuk menciptakan sebuah platform arsitektur yang dapat dikombinasikan dengan berbagai macam keadaan dan kondisi masyarakat dalam hal ini masyarakat perkotaan. Open Architecture sebagai platform dibagi menjadi tiga kategori yaitu 
Commercial, Hosplitality, dan Entertainment. Commercial disini adalah kategori yang terkait dengan hal jual beli jasa maupun barang. Hospitality disini adalah hal-hal yang terkait dengan penerimaan tamu, pengunjung, dan juga pelayanan terhadap masyarakat. Entertainment terkait dengan ekspresi, karena itu erat kaitannya dengan art dan kultur, selain itu terkadang memiliki hubungan dengan edukasi, Ketiga kategori ini dibutuhkan masyarakat terutama masyarakat kota.

\section{Pembelajaran Digital}

Pada masa sekarang yang dimana pengetahuan terkait bidang digital dan teknologi dikatakan menjadi salah satu landasan bagi masyarakat untuk terjun kedalam dunia pekerjaan. Di Indonesia saat ini dapat dikatakan masih kekurangan literasi tetang digital dan teknologi.Salah satu contohnya banyak pelajar yang memasuki pendidikan lebih lanjut dan dunia profesional tanpa keterampilan yang dibutuhkan untuk menerapkan teknologi digital ke pendidikan. Memperluas dan meningkatkan kompetensi digital merupakan salah satu komponen penting dalam pengembangan diri dan kompetitif dalam hal mendapatkan pekerjaan. Dikarenakan hamper $90 \%$ pekerjaan membutuhkan keterampilan digital yang baik. Mereka yang tidak memiliki keterampilan dalam teknologi dan digital yang memadai akan berada pada posisi yang sangat tidak menguntungkan di dunia profesional dan akan sedikit akses informasi.

Literasi digital merupakan sebuah konsep yang terkait dengan kompetensi digital, diperkenalkan oleh Paul Gilster dalam bukunya tahun 1997 dengan nama yang sama. Konsep ini dipahami sebagai kombinasi keterampilan teknis-prosedural, kognitif, dan emosional-sosial. Menurutnya, literasi digital adalah kemampuan untuk memahami dan menggunakan informasi dalam berbagai format dari berbagai sumber ketika disajikan melalui komputer. Literasi digital (JonesKavalier \& Flannigan, 2006) mewakili kemampuan seseorang untuk melakukan tugas secara efektif dalam lingkungan digital, di mana "digital" itu sendiri berarti informasi yang direpresentasikan dalam bentuk angka dan terutama untuk digunakan oleh komputer.

Literasi digital adalah "kesadaran, sikap, dan kemampuan individu untuk secara tepat menggunakan alat dan fasilitas untuk mengidentifikasi, mengakses, mengelola, mengintegrasikan, mengevaluasi, menganalisis, dan menyintesis sumber daya digital, membangun pengetahuan baru, membuat ekspresi media, dan berkomunikasi dengan orang lain, dalam konteks situasi kehidupan tertentu untuk memungkinkan tindakan sosial yang konstuktif, dan merenungkan proses ini". Kemudian, Martin (2009) mengusulkan tiga tingkatan atau tahapan untuk pengembangan literasi, yaitu: Tahap 1 kompetensi digital yang mencakup keterampilan konsep, pendekatan, sikap, dan lainnya; Tahap 2 penggunaan digital yang mencakup aplikasi profesional/disiplin; dan Tahap 3 transformasi digital yaitu inovasi/kreativitas.

\section{Pembelajaran Kuliner}

Salah satu jenis industri yang sedang berkembang pada saat ini adalah industri kreatif. Ekonomi kreatif menurut Badan Pusat Statistik merupakan perwujudan pembangunan yang berkelanjutan dengan kreativitas dalam iklim perekonomian yang berdaya saing dan memiliki cadangan sumber daya terbarukan serta dapat berproses baik tanpa mengandalkan sumber daya alam yang terbatas. Pada saat ini industri manufaktur memiliki 4 subsektor ekonomi kreatif, yaitu kriya, kuliner, fesyen, dan penerbitan. Salah satu subsektor dalam industri kreatif yang berkontribusi cukup banyak dalam industri kreatif adalah subsektor kuliner. Menurut data Survei Industri Manufaktur Tahun 2015, subsektor kuliner memiliki jumlah industri ketiga paling tinggi yaitu 21 persen dari keseluruhan industri kreatif. Saat ini, penelitian yang berkaitan dengan ekonomi kreatif sebagian besar terfokus pada pemetaan industri kreatif di suatu wilayah. Hal ini dikarenakan ekonomi kreatif terdiri dari beberapa sektor yang masing-masing 
daerah memiliki sektor unggulan yang berbeda. Selain itu, penelitian terfokus pada analisis kebijakan pengembangan industri kreatif.

\section{METODE}

\section{Tahap Pengumpulan Data}

Pengumpulan data ini dilakukan dengan cara melakukan survey ke lapangan, wawancara dan observasi dan melakukan studi literatur.

\section{Tahap Analisis}

Metode yang digunakan dalam melakukan analisa adalah :

a. Analisis tapak, yaitu sebuah analisis untuk perancangan agar perancangan dapat dirancang sebaik mungkin untuk menunjang satu dan beberapa kegiatan yang terjadi.

b. Analisis bangunan, yaitu analisis yang menitikberatkan pada kondisi fisik bangunan dengan memperhatikan kondisi lingkungan, tapak, akses, dan keadaan masyarakat sekitarnya. Analisis ini meliputi analisis fungsi, pelaku, aktivitas, dan bentuk.

c. Analisis elemen fisik, yaitu sebuah proses analisis yang berkaitan dengan rancangan spasial lingkungan agar dapat menghasilkan rancangan yang peduli dengan lingkungan. Analisis elemen fisik ini meliputi tata guna lahan, sirkulasi, ruang terbuka, pedestrian, akses, dan pendukung kegiatan.

d. Analisis citra, yaitu analisis yang meliputi jalur, tepian, distrik, simpul, dan petanda.

e. Analisis struktur dan utilitas, yaitu analisis yang berkaitan dengan tapak dan lingkungan sekitarnya. Analisis ini meliputi sistem struktur, sistem penyediaan air besih, drainase, pembuangan sampah, jaringan listrik, keamanan, dan komunikasi.

\section{Tahap Sintesis}

Dalam proses sintesis akan dilakukan sebuah penggabungan hasil analisis yang menghasilkan konsep simbiosis yang akan dijadikan pedoman dalam menyusun konsep perancangan. Konsep ini akan meliputi konsep dasar perancangan, tapak, ruang, bentuk, dan tampilan bangunan.

\section{Pendekatan Arsitektur}

Sustainabillity architecture mengacu pada bangunan yang berfokus pada renewal energy, sustainable material, site development dan quality of indoor ambience. Dasar dari sustainable architecture adalah pengunaan teknik dan material yang ramah lingkungan selama proses pembangunannya, juga berupaya untuk mengurangi dampak buruk dari bangunan melalui konsumsi energi dan pengembangan ruang yang efisien. Penggunaan bahan bangunan yang ramah lingkungan, alami, dan dikombinasikan dengan sumber energi terbarukan menjadikan sustainable architecture menjadi lebih murah untuk dibangun dan dipelihara. Selain bermanfaat bagi lingkungan dan penghematan dari sisi biaya, salah satu manfaat dari sustainable architecture adalah gaya desain yang tidak perlu dikompromikan oleh penekanan pada bahan alami dan konservasi energi.

Pendekatan ini mengacu pada desain yang melakukan pemanfaatan ruang dengan baik sehingga dapat menekan efek buruk terhadap udara, air, dan lingkungan sekitar. Karakteristiknya pendekatan ini umumnya teradapat pada ventilasi yang baik, bukaan yang cukup untuk pencahayaan alami, desain ruang luar dengan banyaknya tanaman, tidak merusak lingkungan, dan tidak menggunakan bahan sintesis ataupun beracun dalam bangunan. 


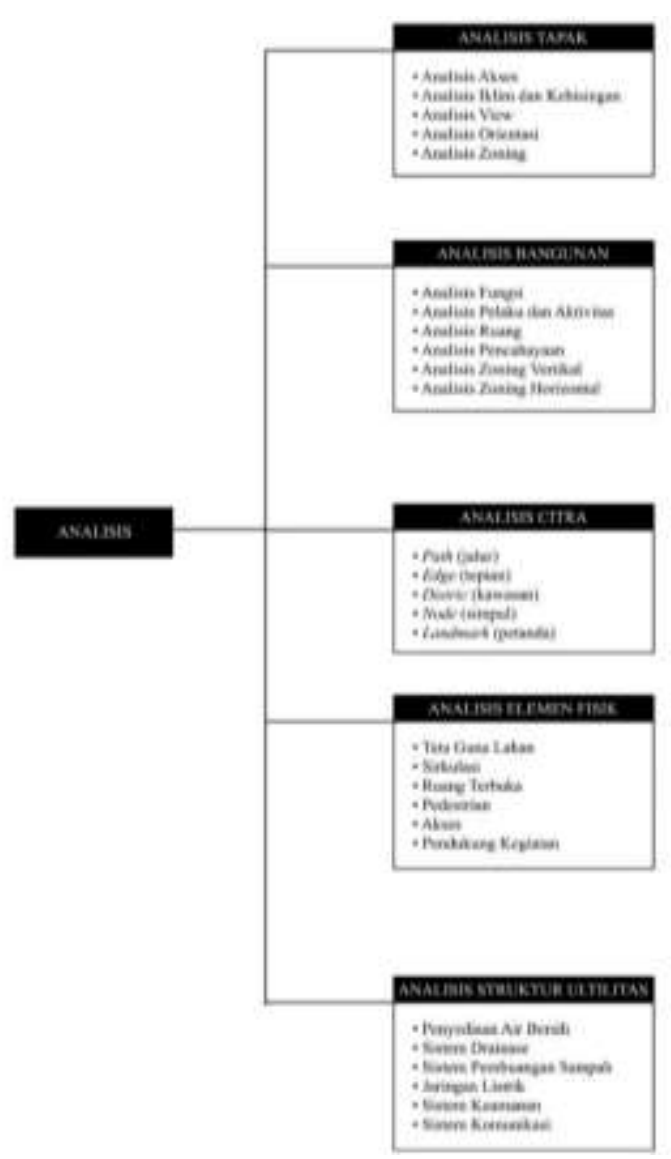

Gambar 3. Proses Metode Analisis

Sumber: Dokumentasi Pribadi, 2020

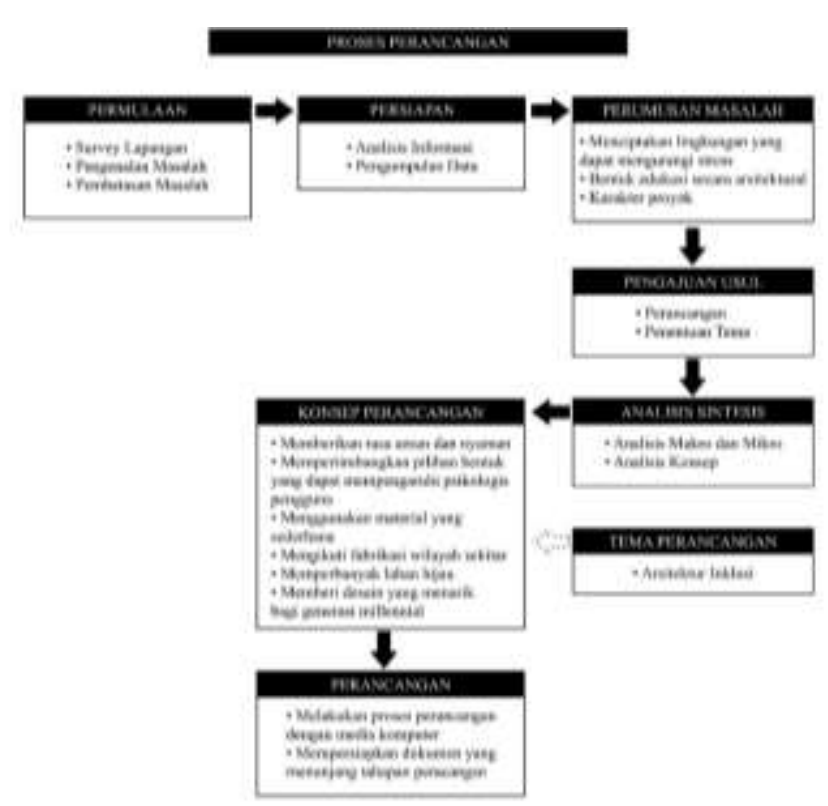

Gambar 4. Proses Metode Sintesis

Sumber: Dokumentasi Pribadi, 2020

\section{DISKUSI DAN HASIL}

Fasilitas pelatihan dan ruang komunitas merupakan sebuah hasil dari berbagai analisis sintesis yang telah dilakukan. Fasilitas yang ditujukan bagi masyarakat sekitar Kota Bambu Selatan merupakan salah satu jawaban untuk memajukan masyarakat sekitar Kota Bambu Selatan yang memiliki image buruk bagi masyarakat sekitar. Selain itu, kurangnya area terbuka dan minimnya 
fasilitas pendidikan menjadi salah satu faktor mengapa fasilitas ini dibentuk. Fasilitas pelatihan dan ruang komunitas ini menyediakan 2 macam workshop yaitu digital dan kuliner. Proyek ini pun turun berperan dalam program pemerintah yang ingin menaikan kualitas SDM masyarakatnya.

\section{Data Tapak}

Kota Bambu Selatan terletak di kecamatan Palmerah, Jakarta Barat, DKI Jakarta. Kelurahan ini berbatasan dengan Tanjung Duren Selatan di sebelah utara, Sukabumi Utara di sebelah barat, Kota Bambu di sebelah timur dan Palmerah di sebelah selatan. Kelurahan ini dihuni oleh 24.957 penduduk yang terbagi menjadi 12.730 laki-laki dan 12.227 perempuan dengan seks rasio 104.11.Tapak terpilih berada dijalan Kota Bambu Selatan dengan lebar jalan muka 4 meter dengan 2 jalur dan memiliki spesifikasi berupa:
a. Luas Tapak : $3150 \mathrm{~m}^{2}$
b. Zonasi : Sub zona perumahan KDB Sedang - Tinggi
c. $\mathrm{KDB}: 60 \%=1890 \mathrm{~m}^{2}$
d. $K L B: 1.2=3780 \mathrm{~m}^{2}$
e. $K B: 2$
f. $K D H: 20 \%$

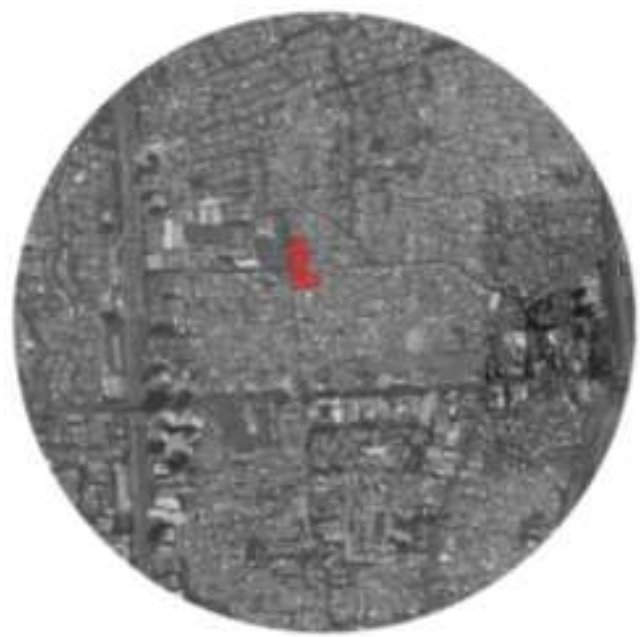

Gambar 5. Site Terpilih

Sumber: Dokumentasi Pribadi, 2020

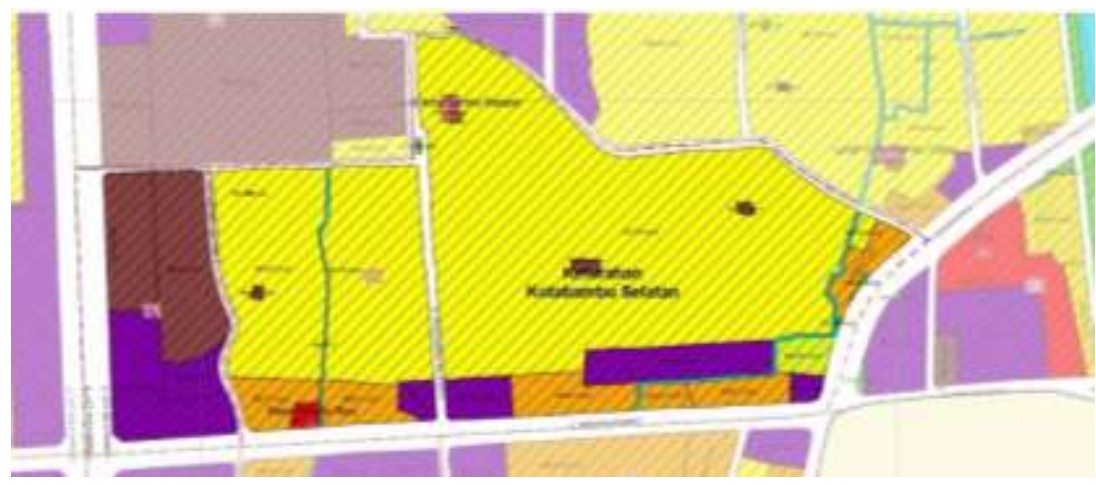

Gambar 6. Peta Tata Guna Lahan

Sumber: RTBL

Pada peta tata guna lahan dapat dilihat hampir keseluruhan lahan di Kelurahan Kota Bambu Selatan diperuntukkan untuk hunian. Dengan beberapa bagian terdapat lahan yang diperuntukkan sebagai campuran dan perkantoran yang berada di pinggir jalan Brigjen Katamso. 
Selain itu dapat dilihat di sebelah timur Kelurahan Kotabambu Selatan terdapat Rumah Sakit Dharmais dan Rumah Sakit Harapan Kita. Dari peta tersebut terdapat data bahwa banyaknya pendatang dari luar Kelurahan Kota Bambu Selatan ini datang untuk menetap adalah sebuah hal yang wajar karena pada tempat ini hampir seluruhnya adalah zona hunian. Pemilik rumah yang sudah lama menetap disini pun banyak yang menyewakan rumahnya kepada pendatang dari luar untuk dikontrakkan atau dijadikan kost-kostan.

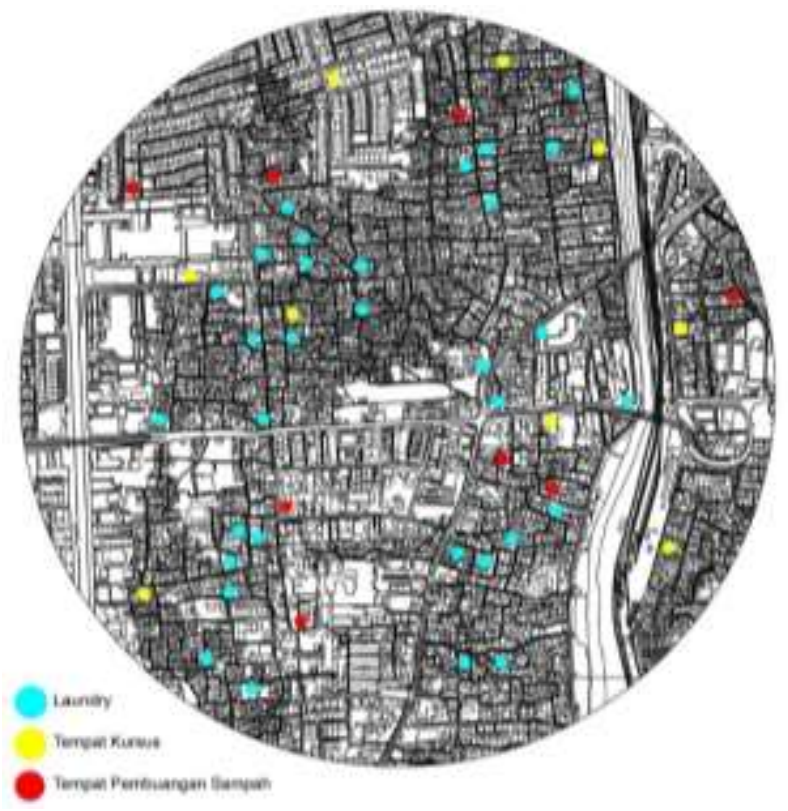

Gambar 7. Mapping Eksisting Penunjang Sumber: Dokumentasi Pribadi, 2020

Berdasarkan hasil mapping, jumlah fasilitas laundri di sekitar kawasan terbilang cukup banyak. Ini menandakan permintaan akan jasa cuci terbilang banyak. Banyaknya jasa cuci merupakan sebuah indikasi bahwa daerah ini memiliki banyak masyarakat dari luar Kelurahan Kota Bambu Selatan. Sedangkan jumlah tempat kursus sedikit, menandakan fasilitas berbasis pendidikan terbilang kurang memadai. Untuk tempat pembuangan sampah, terbilang cukup menampung tiap blok.

\section{Judul Proyek}

Ruang Publik Pengembangan Digital dan Kuliner Masyarakat Kota Bambu Selatan merupakan sebuah wadah bagi masyarakat sekitar Kota Bambu selatan untuk belajar dan mengasah kemampuan mereka agar dapat terjun langsung kedalam masyarakat. Ruang Publik Pengembangan Digital dan Kuliner Masyarakat Kota Bambu Selatan bertujuan untuk menaikan taraf kehidupan masyarakat sekitar dengan dasar potensi yang masyarakat Kota Bambu Selatan miliki, yaitu dibidang kuliner. Dengan melihat daerah sekitar Kota Bambu Selatan yang dimana banyaknya kuliner, proyek ini diharpakan memberikan kesempatan lebih bagi masyarakat Kota Bambu Selatan. Pelatihan digital yang dimiliki proyek ini berlandaskan potensi wilayah. Daerah sekitar Kota Bambu Selatan banyak berdiri perkantoran. Dengan potensi ini, pelatihan digital juga diharapkan dapat meningkatkan kehidupan masyarakat Kota Bambu Selatan. 

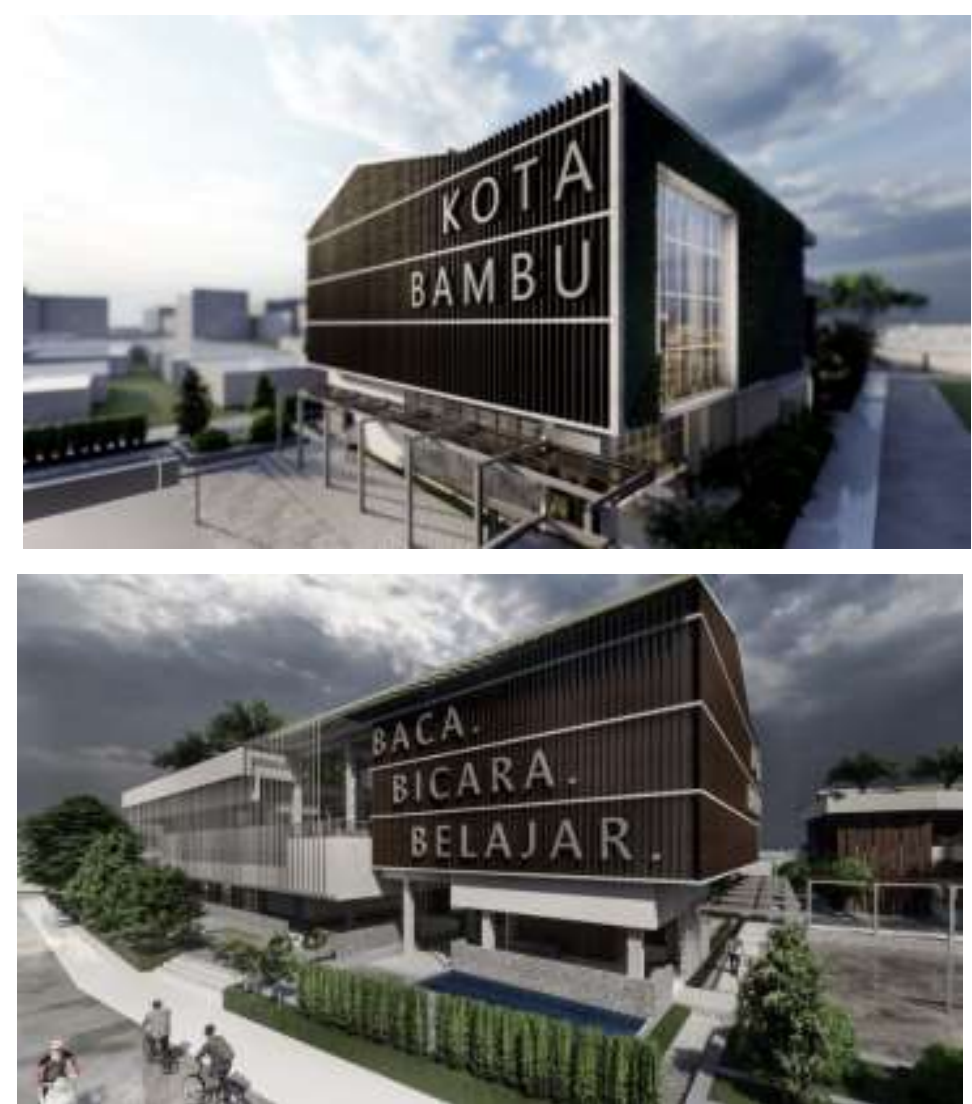

Gambar 8. Tampak Bangunan

Sumber: Dokumentasi Pribadi, 2020

\section{Skema Perancangan}

CONCEPT DEVELOPMENT

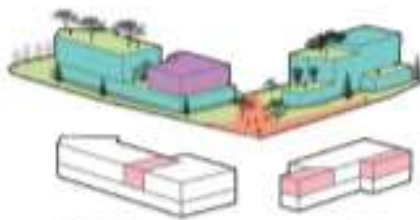

Konsep massa akhir dengan banyak ruang terbuka dan pintu masuk ditengah tapak

Melakukan pemotongan pada massa lantai 2 untuk dijadikan area terbuka

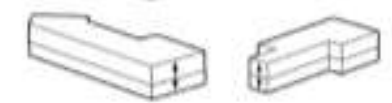

Menambahkan lantai dengan ukuran yang sama

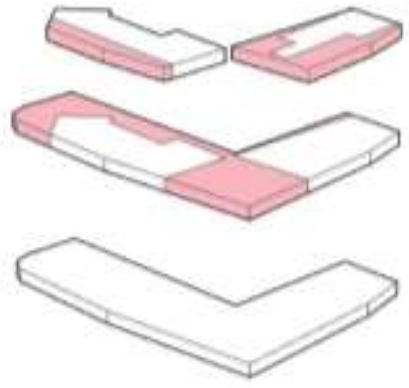

Pemotongan untuk memberikan ruang publik lebih

Peagurangan massa untuk memberikan keiluasaan dan area terbuk:

Bentuk awal berdasarkan dengan bentuk dasar tapak

\section{TAMAN \\ RUANG BERMAIN \\ RUANG BELAJAR \\ ENTRANCE}

Gambar 9. Skema Perancangan

Sumber: Dokumentasi Pribadi, 2020 
Konsep akhir massa menitikberatkan pada pemanfaatan ruang terbuka pada tapak. Pemotongan yang dilakukan pada massa dimaksudkan juga untuk memberikan keleluasaan dan integrasi antara satu massa dengan massa yang lainnya. Kebutuhan akan ruang publik juga menjadi salah satu dasar banyaknya bukaan dan ketersediaan taman. Selain itu, konsep diskusi diruang terbuka yang menjadikan para pelaku diskusi memandang bahwa pembelajaran bukan suatu hal yang kaku dan harus formal. Dengan bentukan massa seperti ini, diharapkan terjadi integrasi antara satu bangunan dengan bangunan lainnya, dan satu kegiatan dengan kegiatan lainnya.

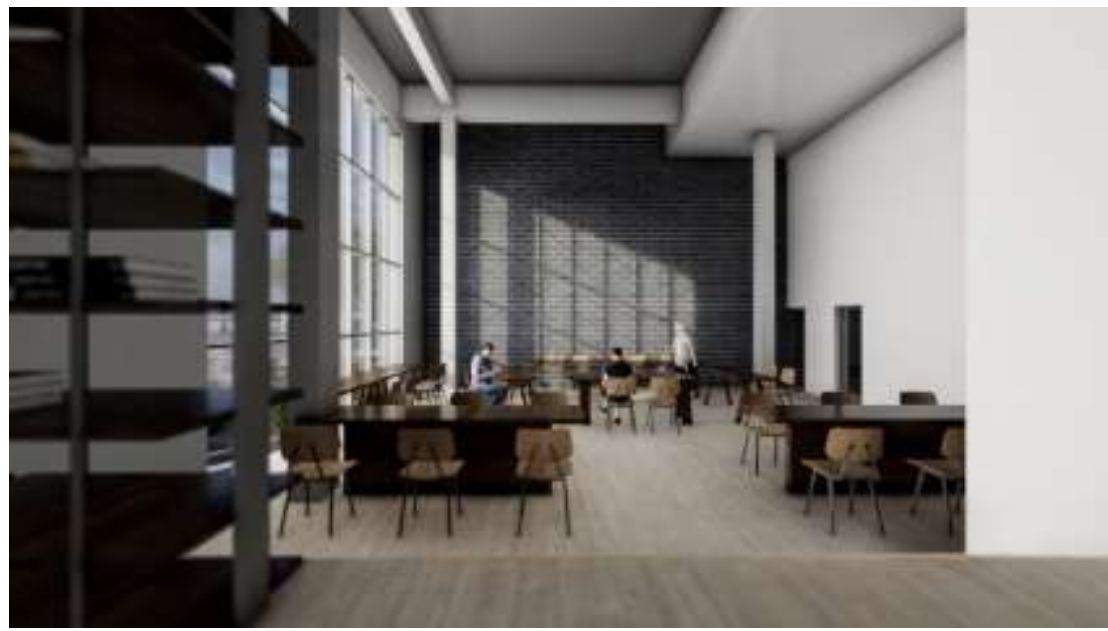

Gambar 10. Ruang Belajar

Sumber: Dokumentasi Pribadi, 2020

\section{Konsep Dasar Bangunan}

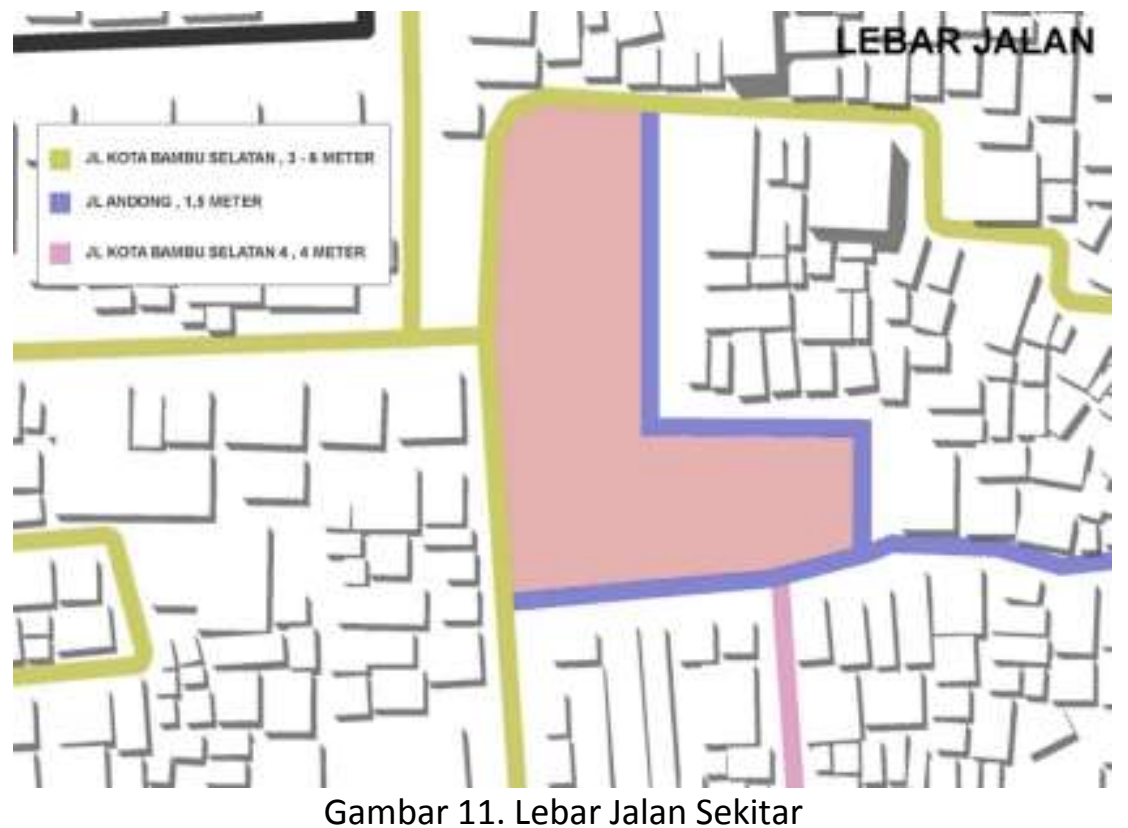

Gambar 11. Lebar Jalan Sekitar

Sumber: Dokumentasi Pribadi, 2020

Ukuran jalan sekitar tapak mempengaruhi mana daerah yang akan dijadikan view utama dari proyek ini. Dilihat dari ukurannya, jalan Kota Bambu Selatan yang ditandai dengan warna kuning merupakan jalan yang paling potensial untuk dijadikan tampak utama karena merupakan jalan utama, memiliki lebar yang cukup, dan merupakan jalan dengan berbagai kegiatan. Disisi lain, jalan Andong dengan warna biru berpotensi menjadi entrance sekunder bagi tapak, dengan 
alasan jalan Andong ini memiliki akses langsung ke arah perumahan yang dimana merupakan sasaran utama bagi proyek berbasis third place ini.

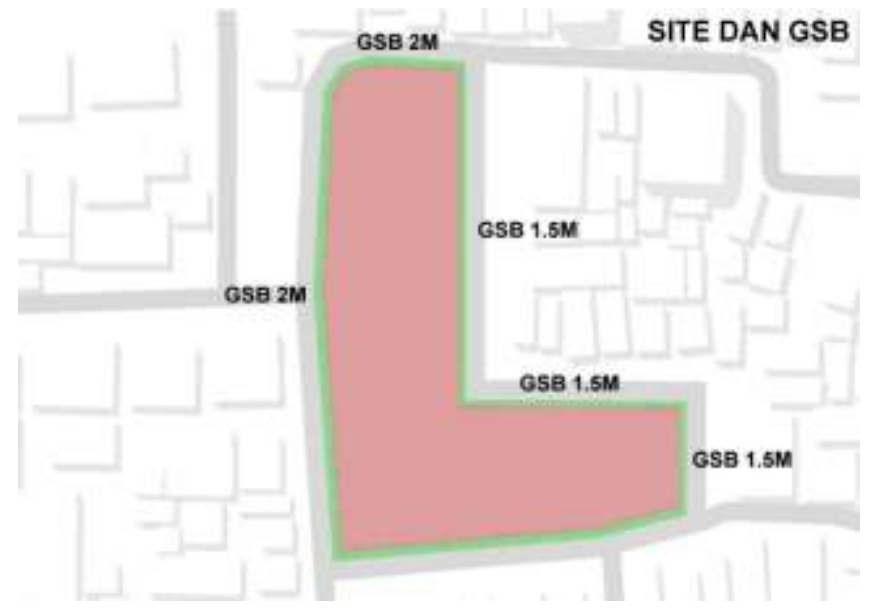

Gambar 12. GSB

Sumber: Dokumentasi Pribadi, 2020

Bentuk tapak seperti ini memiliki potensi baik bagi kawasan sekitarnya. Contohnya seperti GSB yang mengelilingi keenam sisi tapak. Keliling tapak dapat dimanfaatkan sebagai area pejalan kaki atau pedestrian. Pedestrian yang disiapkan tapak ini memiliki peranan cukup penting bagi kawasan dikarenakan kawasan Kota Bambu Selatan ini dapat dikatakan kurang ramah terhadap pejalan kaki. Kawasan ini didominasi oleh jalan raya, sehingga menyulitkan pejalan kaki untuk mengakses kawasan ini dengan rasa nyaman dan aman. Pemanfaatan GSB sebagai pedestrian juga memberikan dampak positif bagi image kawasan dengan menjadi catalyst kawasan yang dimana kedepannya kawasan Kota Bambu Selatan diharapkan mendjadi salah satu kawasan yang ramah terhadap pejalan kaki.

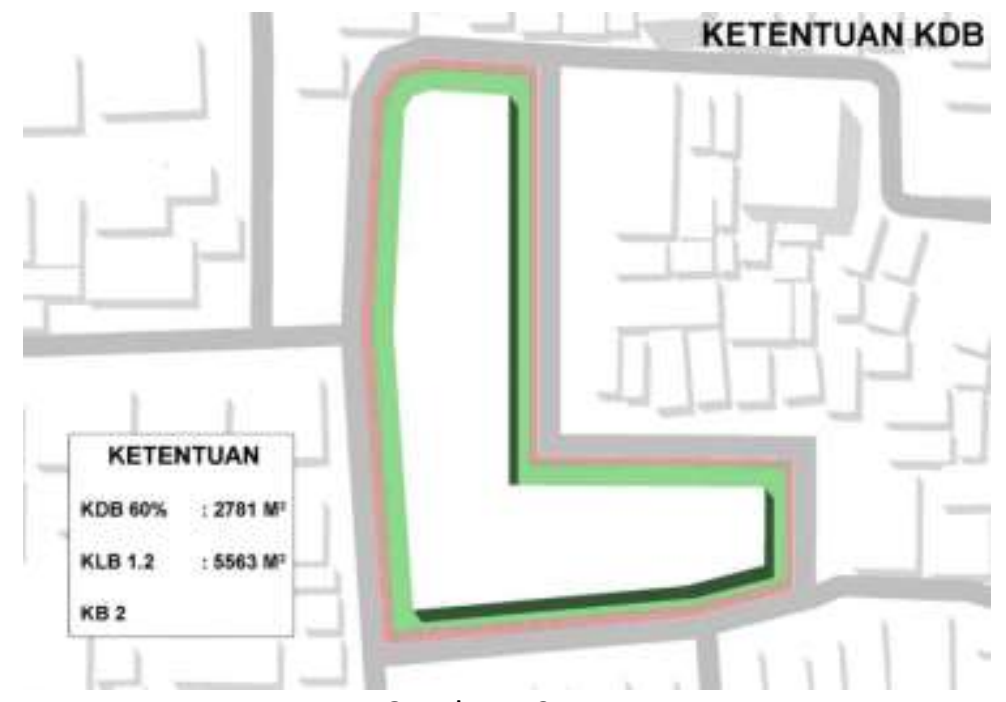

Gambar 13. KDB

Sumber: Dokumentasi Pribadi, 2020

Tapak ini memiliki total luas sebesar $4632 \mathrm{~m}^{2}$. Dengan luas sebesar itu, proyek ini memiliki potensi lantai dasar seluas $2781 \mathrm{~m}^{2}$ dengan $\mathrm{kdb} 60 \%$ dan total keseluruhan luas bangunan sebesar $5563 \mathrm{~m}^{2}$ dengan KLB 1,2. Gambar diatas merupakan proyeksi luas lantai 1 bangunan jika mengikuti ketentuan 60\% KDB yang tertera di tabel RTBL. Dengan luas $2781 \mathrm{~m}^{2}$ pada lantai 1 , banyak potensi ruang yang dapat dimainkan dalam tapak ini. Selain ruang-ruang yang terbentuk, 
terdapat jg potensi untuk mengatur ruang luar bangunan menjadi sebuah ruang luar yang dapat menarik perhatian masyarakat sekitar dan menjadi icon bagi kawasan Kota Bambu Selatan ini.

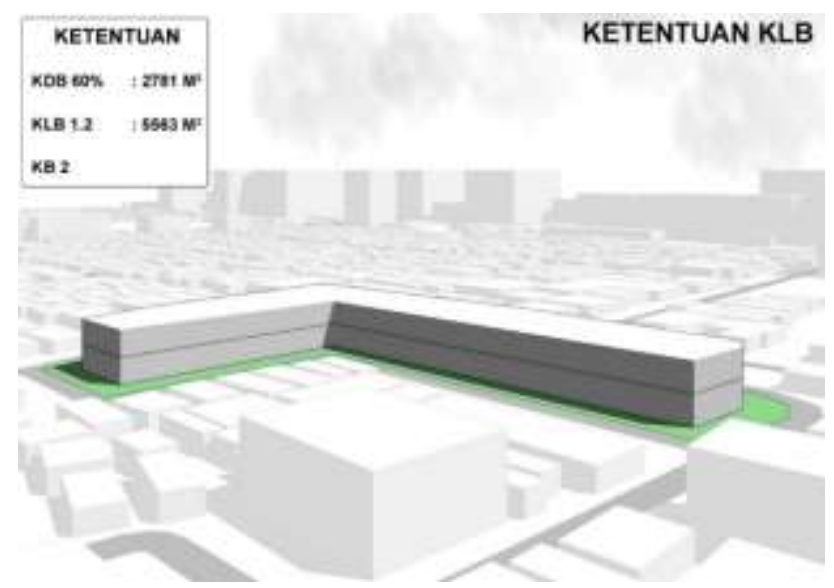

Gambar 14. KLB Secara 3D

Sumber: Dokumentasi Pribadi, 2020

Jika dilihat secara ketinggian bangunan dan pemenuhan standart akan KLB, maka gambar diatas merupakan proyeksi akan bentuk dasar massa bangunan pada tapak ini. Dengan pendekatan yang telah dijabarkan pada skema perancangan, kemasifan dari bentuk dasar massa bangunan ini akan dipecah menjadi beberapa bagian. Seperti area entrance, ruang terbuka, program beserta kegiatannya, dan juga area mana saja yang merupakan area publik dan area semi-publik.

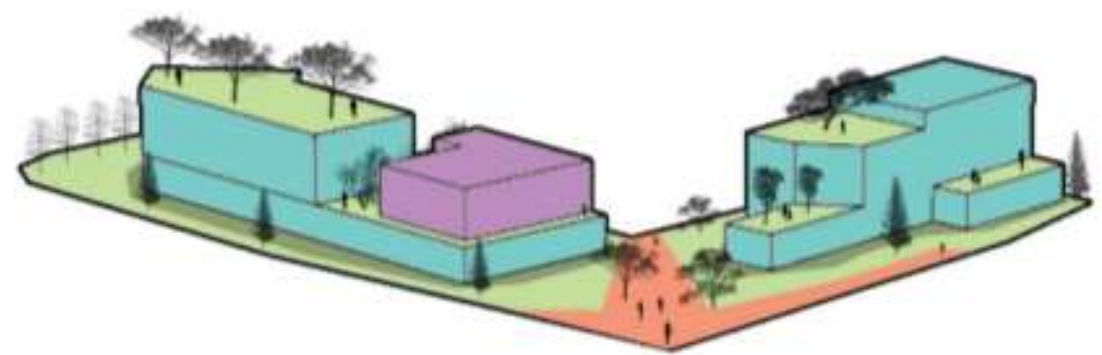

Gambar 15. Konsep Akhir Bangunan

Sumber: Dokumentasi Pribadi, 2020

Konsep akhir bangunan memberikan banyak ruang terbuka untuk diakses oleh pengunjung tapak ini. Kurangnya area terbuka pada kawasan ini menjadi salah satu elemen pendukung dihadirkannya banyaknya ruang terbuka pada bangunan ini. Begitu juga dengan ruang bermain, banyaknya anak usia menengah dan kurangnya area bermain menjadikan bangunan ini salah satu wadah untuk berinteraksi dan bermain untuk anak usia menengah. Penyediaan ruang belajar juga menjadi salah satu tujuan proyek ini untuk meningkatkan taraf hidup masyarakat Kota Bambu Selatan. Dengan adanya ruang belajar yang didesain senyaman mungkin diharapkan mengubah presepsi masyarakat tentang cara belajar.

\section{Sirkulasi Dalam Bangunan}

Pengunjung bangunan dapat memasuki bangunan melewati 3 pintu utama. Masing-masing bangunan memiliki sirkulasi sendiri namun semua bangunan tergabung melalui jalur publik yang berada diluar bangunan. Pengunjung juga dapat mengelilingi tapak untuk duduk di tempat yang telah tersedia dan menikmati lanskap pada tapak. Sirkulasi servis mengunakan akses pada timur bangunan yang dimana servis hanya digunakan untuk loading in dan out barang pada pelatihan kuliner. 


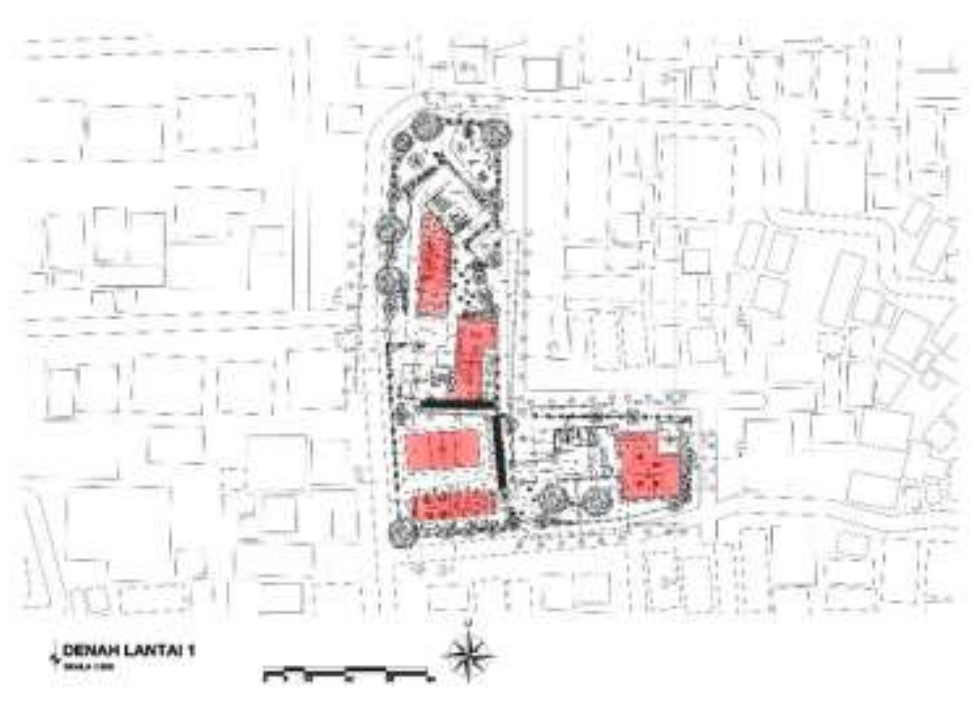

Gambar 16. Bangunan

Sumber: Dokumentasi Pribadi, 2020

\section{Struktur Bangunan}

Struktur rangka bangunan menggunakan struktur beton yang dimana kolom dan balok yang digunakan adalah material beton. Bagian dinding menggunakan bata dan lantainya pun mengunakan plat beton dengan finishing lantai parket dibeberapa titik dan beton yang di polish dibeberapa tempat. Atap pada bangunan ini menggunakan rangka baja ringan dengan penutup atap spandek dengan ketebalan $3 \mathrm{~mm}$.

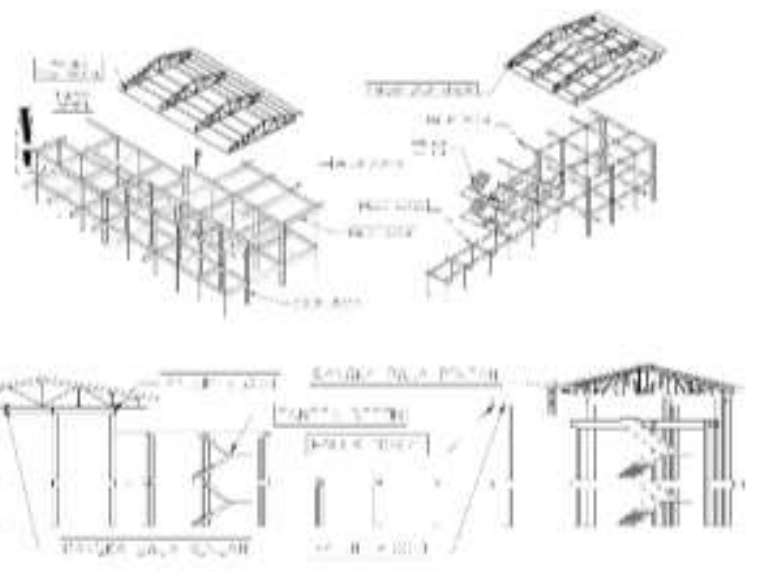

$\rightarrow$ stauktur

Gambar 17. Struktur Bangunan

Sumber: Dokumentasi Pribadi, 2020

\section{Sistem MEP}

Sistem MEP bangunan ini baik kelistrikan, udara, dan pencahayaan dirancang dengan konsep ramah lingkungan. Sistem air pada bangunan ini mengunakan reservoir atas menuju sistem shaft dan menuju reservoir bawah pada sistem air bersih, dan menuju bak kontrol pada sistem air kotor serta kotoran. Sistem kelistrikan dan pencahayaan bangunan juga mengacu pada sustainable architecture yang dimana meminimalisir pengunaan air conditioner agar dapat mengurangi pengunaan energi. Begitu juga dengan pencahayaan yang dimana bangunan ini memaksimalkan pengunaan pencahayaan alami. 

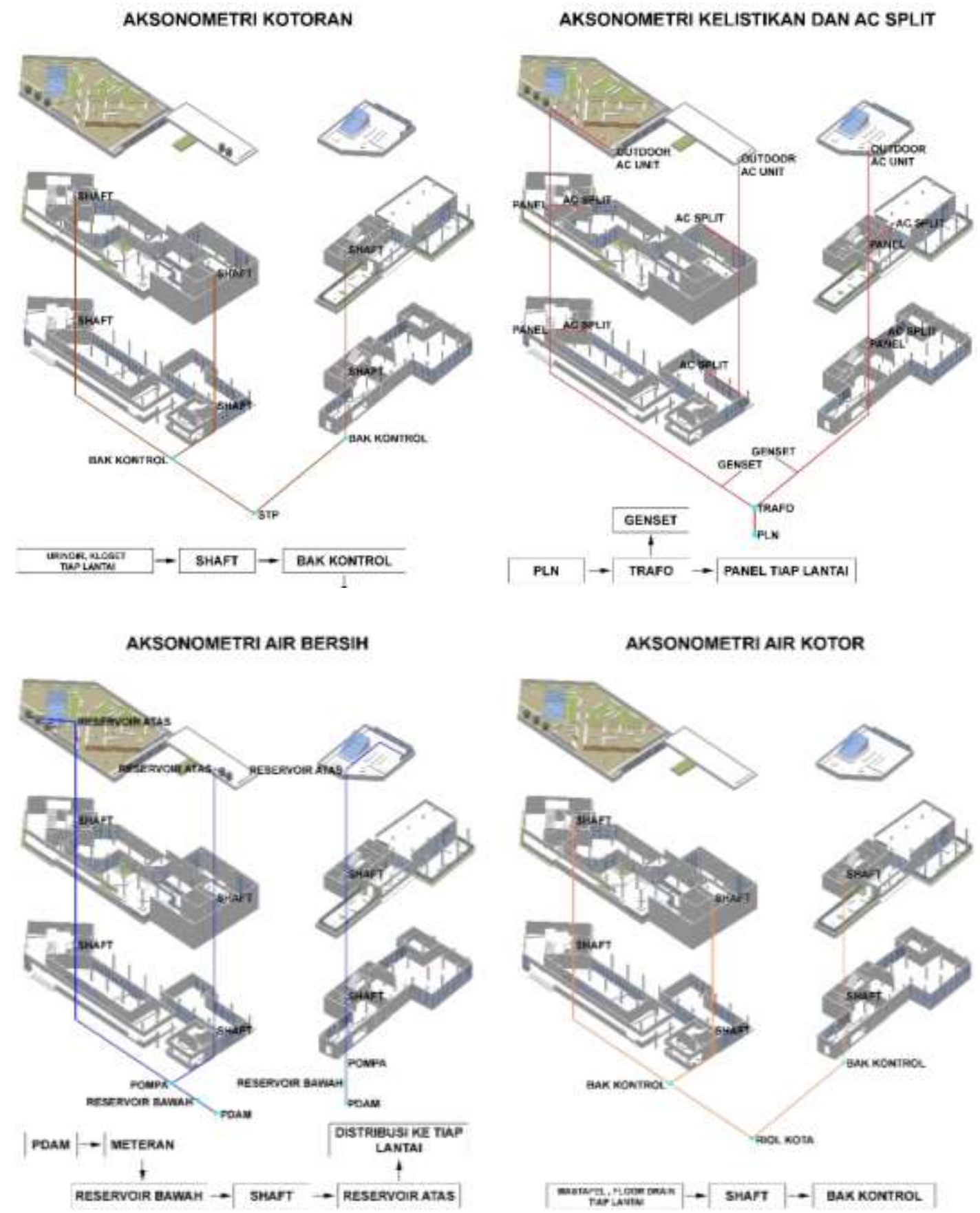

Gambar 18. Sistem MEP Bangunan

Sumber: Dokumentasi Pribadi, 2020

\section{Ruang Publik}

Ruang publik berfungsi sebagai tempat bagi masyarakat atau komunitas di wilayah Kelurahan Kota Bambu Selatan untuk menyalurkan kegiatan yang biasa di lakukan. Kegiatan-kegiatan tersebut dapat menjadikan tempat ini seperti ruang belajar bersama, ruang untuk berdiskusi, tempat bermain dan ruang untuk masyarakat sekitar saling berbagi ilmu sehingga dapat meningkatkan kualitas mereka dalam hal hard skill dan soft skill. 


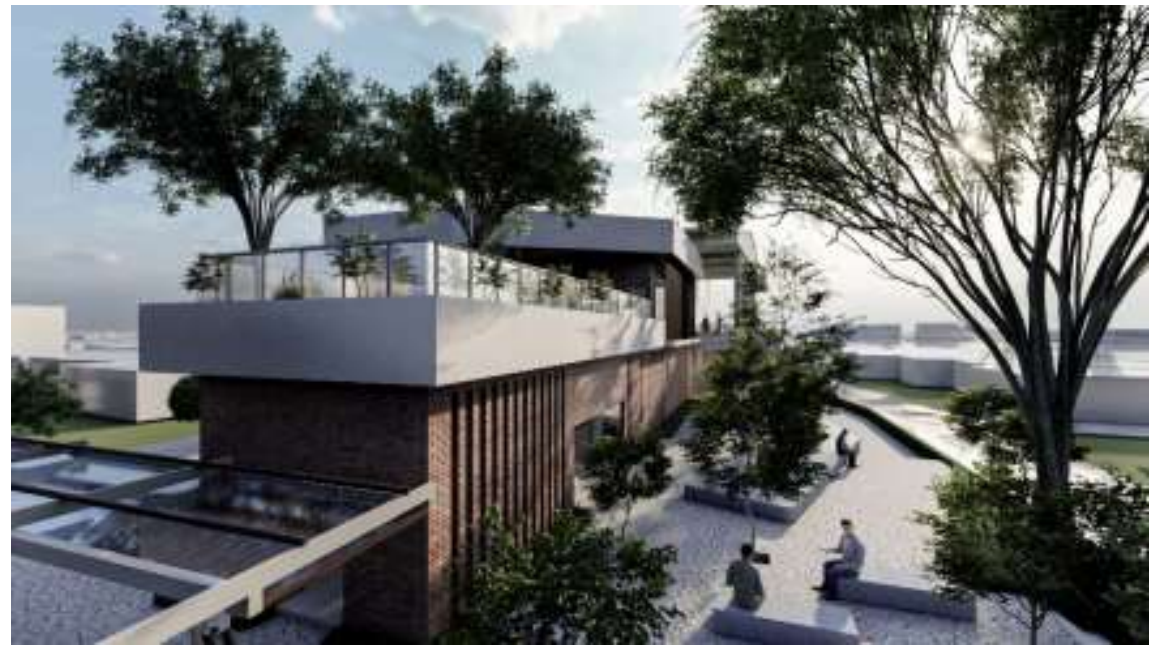

Gambar 19. Area Publik

Sumber: Dokumentasi Pribadi, 2020

Proyek ini memberikan banyak opsi ruang publik pada keseluruhan bangunan. Gambar diatas menunjukan salah satu area publik pada bangunan dengan program pelatihan kuliner. Ruang terbuka seperti ini di desain senyaman mungkin dengan banyak pepohonan agar pengunjung dapat bersantai dan berdiskusi dengan nyaman di semua tempat dalam area bangunan.

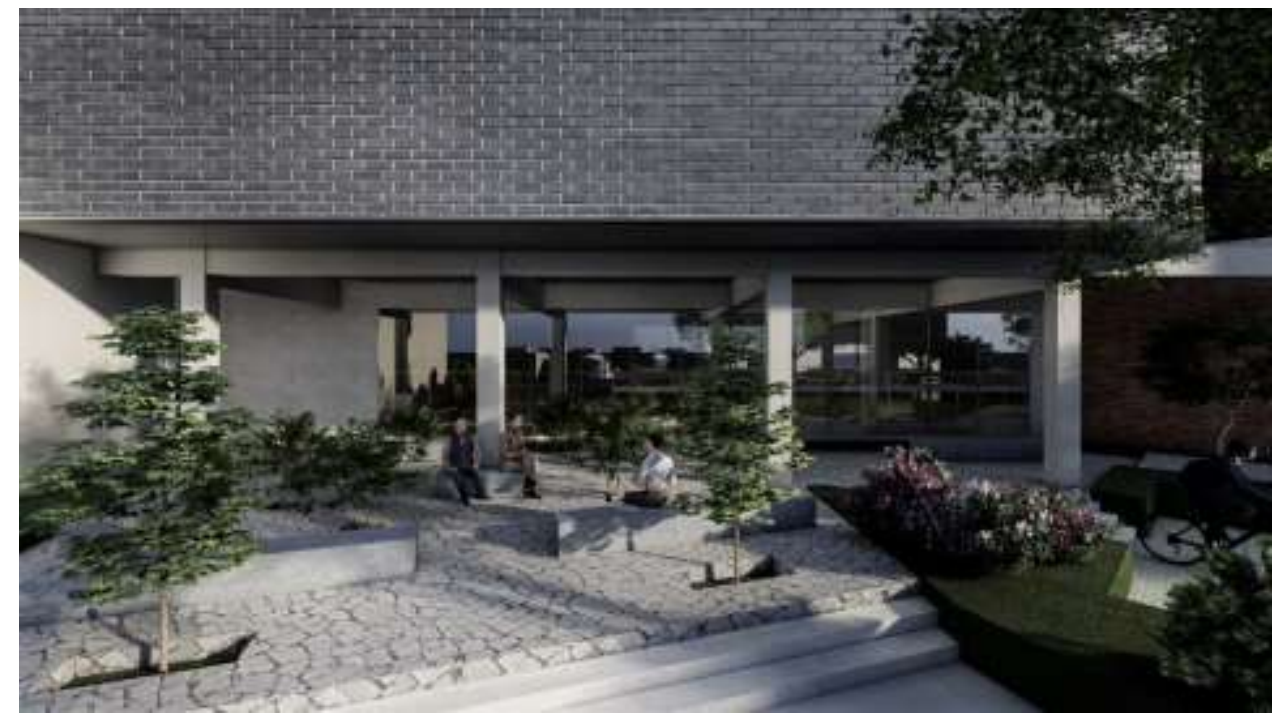

Gambar 20. Area Publik

Sumber: Dokumentasi Pribadi, 2020

\section{KESIMPULAN DAN SARAN}

\section{Kesimpulan}

Perancangan proyek "Ruang Publik Pengembangan Digital dan Kuliner Masyarakat Kota Bambu Selatan" dirancang dengan landasan kebutuhan kawasan Kota Bambu Selatan akan ruang pewadah komunitas untuk masyarakat melakukan interaksi satu sama lain, dan juga memberikan pelatihan bagi masyarakat sekitar agar mereka memiliki hardskill dan softskill guna untuk bekerja dikemudian harinya. Proyek ini berusaha untuk memberikan edukasi kepada masyarakat akan pentingnya cara berinteraksi sosial yang baik dan juga proyek ini berusaha untuk membantu masyarakat Kota Bambu Selatan untuk melakjukan kegiatan ke sesuatu yang lebih berguna. Selain ini juga untuk meningkatkan produktivitas masyarakat sekitar agar dapat perlahan menghilangkan image buruk masyarakat akan daerah Kota Bambu Selatan ini. Program 
yang dirancang ini diharapkan dapat mewadahi kebutuhan masyarakat sekitar Kota Bambu Selatan dan mencetak orang-orang yang memiliki moral tinggi, rasa empati dan simpati, serta dapat berkontribusi bagi masyarakat luas.

\section{Saran}

Saran bagi upaya peningkatan taraf hidup bagi sekelompok masyarakat adalah dengan pengembangan sebuah proyek yang memiliki pendekatan permasalahan sosial yang terjadi pada masyarakat tersebut. Proyek seperti ini seharusnya menargetkan wilayah "rawan" dan butuh pengembangan lebih.

\section{REFERENS}

Karnizora, L. \& Sun, Q. (2014). Industry-level Econometric Estimates of Energy-Capital-Labor Subtitution with a Nested CES Production Function. Atlantic Economic Journal

Martin, A. and Grudziecki. J. (2006). DigEuLit: Concepts and Tools for Digital Literacy Development, Innov.Teach.Learn.Inf.Comput,Sci.

Oldenburg, R. (1997). The Great Good Place. Cambridge: Da Capo Press

Oldenburg, R. (2001). Celebrating the Third Place: Inspiring Stories About the "Great Good Place" at the Heart of Our Communities. New York: Marlowe \& Company.

Soekartawi. (2013). Teori Ekonomi Produksi Dengan Pokok Analisis Fungsi Cobb-Douglas. Jakarta: PT Grafindo Persada. 
